Journal of Applied Veterinary Sciences, 6 (4): 32 -38 (October, 2021).

ISSN: Online: 2090-3308, Print: 1687-4072

Journal homepage : https://javs.journals.ekb.eg

\title{
Occurrence of Staphylococcus piscifermentans among Apparently Healthy Ruminants and Their Handlers in Maiduguri, Borno State, Nigeria
}

\author{
Onyilokwu, S. A. ${ }^{1}$; Adamu, S. G. ${ }^{2}$; Lawan, F. A. ${ }^{3}$ and Aye, A. M. ${ }^{4}$ \\ ${ }^{1}$ Department of Medical Laboratory Sciences, Faculty of Allied and Health Sciences, University of Maiduguri, \\ P.M.B. 1069 Maiduguri Borno State, Nigeria. \\ ${ }^{2}$ Department of Veterinary Public Health and Preventive Medicine, Faculty of Veterinary Medicine, University of \\ Maiduguri, P.M.B. 1069 Maiduguri Borno State, Nigeria. \\ ${ }^{3}$ Department of Veterinary Microbiology, Faculty of Veterinary Medicine, University of Maiduguri, P.M.B. 1069 \\ Maiduguri, Borno State, Nigeria. \\ ${ }^{4}$ Zankli Medical Service, No.1 Ibrahim Tahir Street Mabushi Opposite Federal Ministry of works, Abuja, Nigeria. \\ *Corresponding Author, Adamu, S. G., E-Mail: gidado97@gmail.com
}

\begin{abstract}
This study was conducted to determine the occurrence and antimicrobial susceptibility of Staphylococcus piscifermentans nasal colonization among apparently healthy ruminants and their handlers in Maiduguri, Borno State, Nigeria. A total of six hundred and five (605) samples were collected aseptically using sterile swab sticks (Oxoid, UK) using a simple random technique from the ruminants and their human handlers at the Maiduguri central abattoir and livestock market (Kasuwan shanu). One hundred and fifty-one (151) samples were collected from each species (cattle, sheep and goat), while 152 samples were collected from animal handlers. The samples were immediately subjected to standard bacteriological analysis. A total of 195 (32.2\%) coagulase-negative Staphylococcus species (CoNS) were presumptively identified; out of the 195 identified CoNS, 9 (4.62\%) was Staphylococcus piscifermentans nasal colonization. The results revealed that out of 9 isolates, S. piscifermentans was highly isolated 4(8.3\%) from sheep, followed by cattle and human handlers $2(3.8 \%)$ respectively, and the least was from goats $1(2.3 \%)$. Meanwhile, all the $9(4.62 \%)$ isolates were negative for both tube and slide coagulase test. However, they were positive for DNase, Ornithine Decarboxylase (ODC) test, betta - hemolysis and synergistic hemolysis. 4(44.4\%) of the 9 isolates were positive for Staphylococcus Protein A (SPA) virulence gene, none $0(0 \%)$ for mecA virulence gene, and 5(55.6\%) were positive for slime (Biofilm) production. The antibiotic susceptibility pattern of these isolates was found to be highly variable to all the used drugs. Therefore, it is concluded that Staphylococcus piscifermentans isolated from these ruminants and their handlers contain virulence genes that could be responsible for pathogenicity. There is a need for more studies using higher technologies in other parts of the country to reveal the thorough status of the disease in Nigeria.
\end{abstract}

Keywords: Handlers, Occurrence, Piscifermentans, Ruminants, Susceptibility profiles.

\section{INTRODUCTION}

Staphylococcus piscifermentans are Grampositive, catalase-positive, Oxidase-negative, facultative anaerobic cocci organisms found in singles pares and clusters. It belongs to the Coagulase Negative Staphylococcus species (CoNS) Onyilokwu et al., (2016). It is a rare strain that is biochemically and phylogenetically most closely related to
Original Article:

DOI:https://dx.doi.org/10.21608/javs.2 021.88440.1094

Received :30 July, 2021.

Accepted:03 September, 2021.

Published in October, 2021.

This is an open access article under the term of $t$ Creative Commons Attribution 4.0 (CC-B International License . To view a copy of tl license, visit:

http://creativecommons.org/licenses/by/4.0/

J. Appl. Vet. Sci., 6(4): $32-38$.
Staphylococcus carnosus carnosus; Staphylococcus carnosus utilise and Staphylococcus condiment (Shubham et al., 2018). In addition, CoNS like $S$. condimenti, $S$. equorum, $S$. piscifermentans and $S$. succinus belonging to the microbiota of spontaneously fermented foods (Shubham et al., 2018).

They are common colonizers of both animals and humans' anterior nare and ear canals (Surkha $\boldsymbol{e t}$ al., 2011). While Stetina reported the isolation of $S$. 
piscifermentans from faeces of healthy dogs (Stetina $\boldsymbol{e t}$ al., 2005), Yasser, however, reported the isolation of the same organisms from teeth of an apparently healthy cow in a dairy farm (Yasser et al., 2018). Coagulasenegative staphylococcus species have long been considered opportunistic pathogens and were rarely reported to cause severe infections. However, due to the combination of the increase in the number of hospitalized immunocompromised patients, CoNS have become the major cause of nosocomial bloodstream infections. They are found to account for $9 \%$ of nosocomial infections (Bodonaik and Moonah, 2006). Hajar and Hamid (2013) recently reported the isolation of Staphylococcus piscifermentans from human brain abscess samples. In a related work, Chinwe et al., (2018) reported the isolation of the $S$. piscifermentans from ready-to-eat meat in Enugu, Southeastern Nigeria.

This rare coagulase-negative germ of Staphylococcus species was originally isolated from fermented fish, fermented fish sauce, and fermented shrimp in Thailand (Hajar and Hamid, 2013; Shubham et al., 2018). Staphylococcus piscifermentans, a non-pathogenic Gram-positive Staphylococcal species, are used in combination with $S$. census and $S$. condimental as starter cultures for fish fermentation and other food processing Industries (Shubham et al., 2018). Hajar and Hamid also reported the isolation of the organism as lactic acid bacteria strain Staphylococcus piscifermentans from Malaysian traditional fermented shrimp called the Cincaluk (Hajar and Hamid, 2013).

Staphylococcus piscifermentans can easily be isolated from routine media such as blood agar, MullerHinton agar and Mannitol salt agar, depending on the media used with its characteristic odour as its usual indicator. Compare with other CoNS, Staphylococcus piscifermentans is generally sensitive to antibiotics used against Staphylococci. It is then often possible to use ampicillin, penicillin, and methicillin to treat possible infections caused by this organism. On record, various Staphylococcus species of both coagulases are positive and negative $(S$. schleiferi, $S$. sciuri, $S$. simulans, S. xylosus, S. lentus, $S$. aureus and $S$. epidermidis) have already been isolated from apparently healthy ruminants and their handlers. Additionally, S. piscifermentans has also been described and isolated from tuna candy products (Hwang et al., 20103). However, this is the first time $S$. piscifermentans are isolated from ruminants and their handlers in Maiduguri, Borno State, and the study area.

Despite the risk associated with animal farming and the emergence of CoNS as a potential pathogen causing disease, the business of livestock farming continues to thrive, most especially in Northern Nigeria and particularly in Maiduguri, the study area. There is a paucity of information on $S$. piscifermentans nasal colonization in ruminants and their handlers in Maiduguri, Borno State, Nigeria. The health risks posed by Staphylococcus piscifermentans nasal colonization in ruminants and their human handlers in the study area may be significant and need to be investigated. The epidemiological information on $S$. piscifermentans nasal colonization among apparently healthy ruminants and their handlers in Maiduguri will form baseline data to guide public health intervention programmes and empirical treatments to suspected cases of S. piscifermentans.

The study was to determine the occurrence, distribution, virulence markers and antimicrobial susceptibility profile of $S$. piscifermentans nasal colonization among apparently healthy ruminants and their handlers in Maiduguri, Borno State, Nigeria.

\section{MATERIIALS AND METHODS}

\section{Ethical approval:}

The samples collected for this study were nasal swabs from the nasal carriageway of ruminants (cattle, sheep and goat) and their handlers at the Maiduguri central abattoir and livestock market (Kasuwan shanu). The samples collected for this study were nasal swabs from the nasal carriageway of ruminants (cattle, sheep and goat) and their handlers at the Maiduguri central abattoir and livestock market (Kasuwan shanu). Ethical approval was not collected because we seek the consent of the owner of the animals before the samples were collected. Standard sample collection for microbiological procedures was strictly observed.

\section{Study area:}

The study was conducted in Maiduguri livestock market (Kasuwan - shanu) jointly with Maiduguri central abattoir, where the animals are brought for sale and slaughtered for consumption. Maiduguri is located in the arid zone of Borno State with an area of about $69436 \mathrm{~km} 2$ and lies within latitude 10-130N and longitude 12-150E. It lies within the Savannah with low records of rainfall. It has two seasons, the dry season between October and May, followed by a short rainy season from early June to early October. The state is located in the North-Eastern part of Nigeria bounded to the Republic of Niger in the West, Chad republic in the North East and the republic of Cameron in the South East as shown in figure 1 below. It has a population of about 4,558,668 and ranked 12th in the country according to the 2005 national census before the advent of the Boko- Haram insurgence in 2009 to date ( Fig.1). 


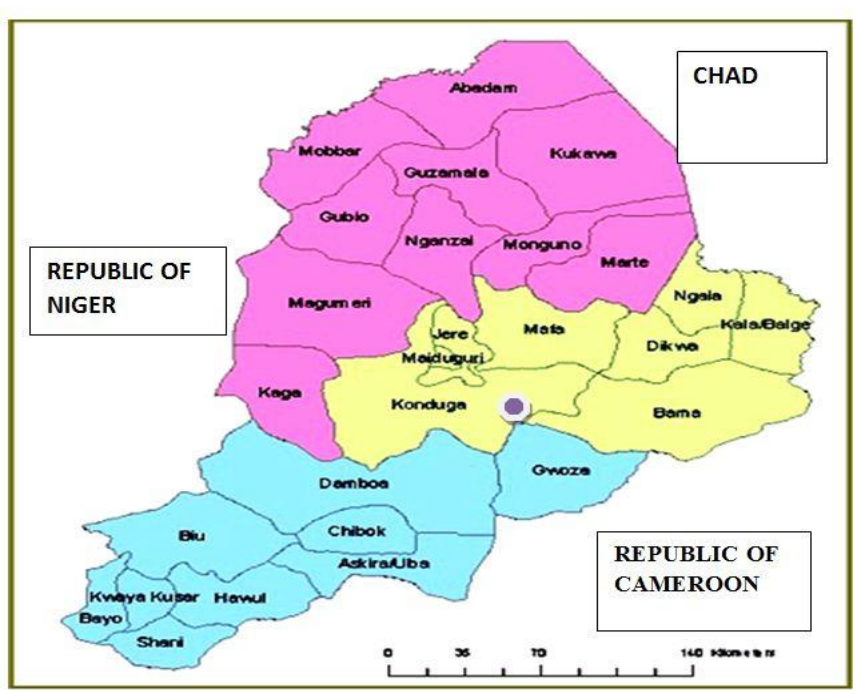

Fig.1: Map of Borno State showing Maiduguri at the centre (with yellow colour) where the Sample was collected.

\section{Sample collection:}

A total of six hundred and five (605) nasal swab samples were aseptically collected for bacteriological examinations from ruminants (cattle, sheep and goats) and their handlers in the Maiduguri Livestock market and the central abattoir. All the samples were collected using a sterile swab (Oxoid, UK) with broth medium from apparently healthy cattle $(n=151)$, sheep $(n=151)$, goats $(\mathrm{n}=151)$ and handlers $(\mathrm{n}=152)$, respectively. Four hundred (400) samples were collected from the abattoir; the 205 samples were collected from the livestock market the following day using simple random sampling. The samples were collected by gently inserting the sterile swab sticks into each nostril and rotated in a circular manner on both nares of the animals and their handlers to ensure adequate content with the mucus membrane of the nostrils and the tip is at the nasal ostium level. In a Stuart transport medium, the samples were immediately transported to the Veterinary Microbiology Laboratory, Faculty of Veterinary Medicine University of Maiduguri. Analysis of all the samples commenced immediately less than 2 hours after the collection.

\section{Bacterial isolation:}

The nasal swab samples collected were aseptically and systematically cultured on Mannitol salt agar (MSA) (Oxoid, UK) using streak plate method and incubated aerobically at $37^{\circ} \mathrm{C}$ for $24-48 \mathrm{hrs}$ in 5 to $7 \% \mathrm{CO}_{2}$, according to the method of Shubham $\boldsymbol{e t}$ al., (2018). Presumptive S. piscifermentans colonies were further sub-cultured onto fresh mannitol salt agar (MSA) and 5\% Sheep blood agar (Oxoid, UK) in order to obtain pure colonies of the organisms and the hemolytic pattern of the bacteria. The presence of growth, colour, average colony size, margin surface elevation, opacity and consistency of colonies produced by the isolate on mannitol salt agar and 5\% Sheep blood agar (Oxoid, UK) were noted including the haemolytic characteristics.

\section{Identification of the isolated species:}

All the presumptive colonies were subsequently subjected to standard biochemical Laboratory tests as Gram staining, catalase test, modified oxidase test, rapid slide agglutination test for clumping factor, tube coagulase production test using human plasma and acid production from various sugars. Further test includes DNase (Salubris, Turkey), Slime (Biofilm) formation according to the method of Bannerman and Paecok, (2007), synergistic hemolysis and Ornithine Decarboxylase (ODC) were carried out to identify $S$. piscifermentans and finally analysis in Staphylococcal API test Kits (Biomereux, UK).

\section{Antimicrobial susceptibility testing:}

Kirby determined antimicrobial susceptibility testing of all the isolates- Bauer disc-diffusion technique using Muller - Hinton agar (Oxoid, England) approved by the Clinical Laboratory Standard Institute CLSI/NCCL, (2014). The antibiotics used for the test include Gentamycin, Penicillin, Oxacillin, Chloramphenicol, Ciprofloxacin, Clindamycin, Sulphamethaxazole, Streptomycin, Tetracycline, Rifampicin and Vancomycin. All the antibiotics were produced and obtained by Oxoid, England. These tests were all conducted using Muller-Hinton agar (MHA) (Remel, England) according to the protocol of (CLSI/NCCLS (2014). All the isolates identification was further confirmed by polymerase chain reaction amplification and sequence analysis of 165-rRNA (ribosomal Ribonucleic Acid). The organism's ability to produce biofilm was performed and measured as described by Monk et al., (2008).

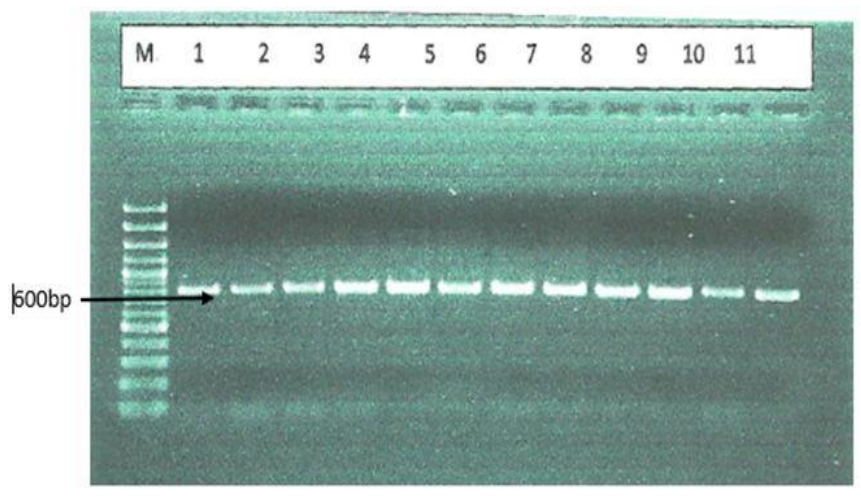

Fig. 2: Amplification of Staphylococcus piscifermentans from nasal colonization swab samples of cattle, Sheep, Gaots and Animal handles. 16S-rRNA genes amplification yields 600bp fragment (Lane's 4-10) to confirm $S$. piscifermentans isolates.

Lane M: DNA molecular marker (100bp ladder).

Lanes 1-3: positive control marker.

Lane's 4-10 products of $S$. piscifermentans $s$ isolates.

Lanes 11-12 control 


\section{Statistical analysis:}

The results of the total $S$. piscifermentans isolated from the nasal carriageway among the apparently healthy ruminants and their handlers were analysed using Statistical Package for Social Sciences (SPSS) version 21.0 statistical software and the Chisquare test at $\mathrm{P}<0.5$ was considered significant.

\section{RESULTS}

A total of $9(4.62 \%)$ S. piscifermentans were isolated from all the 195 coagulase-negative Staphylococcus isolates. Out of these $9(4.62 \%)$ S. piscifermentans isolates, $2(3.8 \%)$ from cattle and human handlers, $4(8.3 \%)$ were from sheep 1(2.3\%) isolated from goats.

Table1: Staphylococcus piscifermentans species isolated from cattle, sheep, goats and animal handlers.

\begin{tabular}{cccc}
\hline Source & $\begin{array}{c}\text { Number } \\
\text { of } \\
\text { samples }\end{array}$ & $\begin{array}{c}\text { No of the } \\
\text { CONS } \\
\text { isolated }\end{array}$ & $\begin{array}{c}\text { Number of } S . \\
\text { pisifermentans }\end{array}$ \\
\hline Cattle & 151 & $52(26.7)$ & $2(3.8 \%)$ \\
\hline Sheep & 151 & $48(26.6 \%)$ & $4(8.3 \%)$ \\
\hline Goat & 151 & $43(22.0 \%)$ & $1(2.3 \%)$ \\
\hline Handlers & 152 & $52(26.7 \%)$ & $2(3.8 \%)$ \\
\hline Total & 605 & $195(32.2 \%)$ & $9(4.6 \%)$ \\
\hline
\end{tabular}

All the $9(4.62 \%)$ S. piscifermentans were negative for both slides and tube coagulase test, but positive for Esculin, Nitrate reduction, Methyl- red, Bacteriocin activity, DNase, ODC, Urease and mannitol fermented. However, none of the $9 S$. piscifermentans isolate showed biofilm (slime) formation.16S-rDNA gene sequencing was used to verify, identify and authenticate all the isolates obtained from phenotypic and biochemical tests. All the 9 S. piscifermentans isolates were susceptible to all the antibiotics tested with varying degrees of the zone of inhibition except for tetracycline.

Table2: Prevalence of virulence genes of $S$. piscifermentans isolated from cattle, sheep, goats and animal handlers.

\begin{tabular}{cccc}
\hline & \multicolumn{2}{c}{ Virulence } \\
\cline { 3 - 4 } Source & $\begin{array}{c}\text { No. of } S . \\
\text { Genes }\end{array}$ \\
\cline { 3 - 4 } $\begin{array}{c}\text { pisifermentans } \\
\text { isolate }\end{array}$ & $\mathrm{A}$ & SPA \\
\hline Cattle & 2 & 0 & 2 \\
\hline Sheep & 4 & 0 & 0 \\
\hline Goats & 1 & 0 & 0 \\
\hline $\begin{array}{c}\text { Animal } \\
\text { handlers }\end{array}$ & 2 & 0 & 2 \\
\hline Total & 9 & 0 & 4 \\
\hline
\end{tabular}

Table3: Antimicrobial susceptibility of Staphylococcus piscifermentans isolated from Cattle, Sheep, Goats and their handlers

\begin{tabular}{llllllllllllll}
\hline Source & $\begin{array}{l}\text { No.of } \\
\text { samples }\end{array}$ & $\begin{array}{l}\text { No.of } \\
\text { Isolates }\end{array}$ & TET & $\begin{array}{l}\text { PE } \\
\mathrm{N}\end{array}$ & GEN & CIP & ME & CH & VR & KN & S & $\begin{array}{l}\text { AM } \\
\text { P }\end{array}$ & E \\
\hline Cattle & 151 & $2(3.8)$ & $2(100)$ & $0(0)$ & $1(50)$ & $0(0)$ & $0(0)$ & $0(0)$ & $0(0)$ & $0(0)$ & $0(0)$ & $0(0)$ & $0(0)$ \\
\hline Sheep & 151 & $4(8.3)$ & $4(100)$ & $00)$ & $0(0)$ & $0(0)$ & $0(0)$ & $0(0)$ & $0(0)$ & $0(0)$ & $0(0)$ & $0(0)$ & $0(0)$ \\
\hline Goats & 151 & $1(2.3)$ & $1(100)$ & $0(0)$ & $0(0)$ & $0(0)$ & $0(0)$ & $0(0)$ & $0(0)$ & $0(0)$ & $0(0)$ & $0(0)$ & $0(0)$ \\
\hline Animal & 152 & $2(3.8)$ & $1(50)$ & $0(0)$ & $0(0)$ & $0(0)$ & $0(0)$ & $0(0)$ & $0(0)$ & $0(0)$ & $0(0)$ & $0(0)$ & $0(0)$ \\
Handlers & & & & & & & & & & & & & \\
\hline
\end{tabular}

\section{DISCUSSION}

Out of the 605 nasal swabs samples collected from the ruminants (cattle, sheep and goats) and their handlers, a total of 195 (32.5\%) CoNS species were isolated. The $(32.5 \%)$ overall occurrence of CoNS species isolated from the nasal carriageway of apparently healthy ruminants and their handlers in the present study is higher than the 3.2\% reported in South
Africa by Nyenje et al., (2015). It is also higher than the $9.4 \%$ reported by Chinwe et al., (2018) and 28\% reported by Mashak et al., (2015) in Teheran Province, Iran from vended RTE meats. The differences could be due to differences in the sources of samples and the geographical location of the samples. Environmental conditions such as the dusty path to the livestock market and even in the abattoir before slaughter in the study area may have also greatly contributed to the 


\section{Occurrence of Staphylococcus piscifermentans among.......}

high occurrence of this organism Staphylococcus piscifermentans and hence the higher prevalence being reported.

Out of these 195 isolates, $9(4.6 \%)$ were confirmed to be $S$. piscifermentans, slightly higher than the $1(4.2 \%)$ prevalence rate reported by Chinwe et al., (2018) from vended Ready to Eat (RTE) meats and 2 $(0.8 \%)$ by Yasser et $\boldsymbol{a l}$., (2018) isolated from bovine intramammary infections and teat apex colonization. However, the overall prevalence rate of $9(4.6 \%)$ of $S$. piscifermentans in this study is lower than the total 10 isolates identified as Staphylococcus piscifermentans based on biochemical and molecular characterization by Shubham et al., (2018) associated with traditional fermented fish products of Northeast India.

Coagulase-negative Staphylococcus species, though regarded as recently being recognized, especially in patients with underbelly devices, are among the most commonly isolated bacteria in the clinical microbiology laboratory Von Eiff and Heilmann, (2002). However, there has not been any report of a case of an outbreak of disease or infection caused by S. piscifermentans to our knowledge. The present study showed no statistical differences between $S$. piscifermentans isolation rate among the four sources of samples. Major possible means of differentiating S. piscifermentans from other CoNS and $S$. aureus is by a negative coagulase test, a positive PYR reaction and ODC positive activity. It becomes important to differentiate because $S$. piscifermentans can easily be misidentified as $S$. aureus due to some certain characteristic of $S$. piscifermentans that mimics that of $S$. aureus such as haemolysis on blood agar plate after $24 \mathrm{~h}$ growth and the colonial morphology that often resembles that of $S$. aureus (Hellbacher et al., 2006).

The upper respiratory tract has been recognized as a major ecological site for various bacteria migrating to a neighbouring sterile site and cause mild to severe infection and invasive diseases (Kassis et al., 2009). Studies have shown that the upper respiratory tract of man and animals may be an important reservoir of multiple antibiotic-resistant CoNS with $S$. piscifermentans inclusive has been largely unreported in ruminants and their human handlers. However, Ruminants animals in this part of the country have remained a very important source of livelihood due to the huge income yield. Hence, the presence and identification of this pathogen possess serious public health and economic concern.

Economically, Ali et al., (2009) stated the use of S. piscifermentans as a lactic acid bacteria (LAB) that produce lactic acid as the result of carbohydrate fermentation that is widely used as a starter culture in the dairy, meat and vegetable fermentation industries. $S$. piscifermentans are also useful in flavour development and food preservation Ali et al., (2009). It is also said to produce a variety of compounds with antimicrobial activity, such as organic acids, hydrogen peroxide and bacteriocin (O-Sulivan et al., 2002). The isolation of $S$. piscifermentans in this study confirmed the nasal carriageway as the predilection site of this organism. It indicates that S. piscifermentans can be harvested from this site and used for the abovementioned benefits. The clinical relevance of $S$. piscifermentans was first described when it was isolated from faeces of healthy dogs (Stetina $\boldsymbol{e t}$ al., 2005), human brain abscess samples (Hajar and Hamid, 2013) and teeth of an apparently healthy cow in a dairy farm (Yasser et al., 2018).

In the present study, all the $9 \mathrm{~S}$. piscifermentans isolates were positive for ODC, DNase, esculine and urease, which agrees with the report of other previous studies. In this same study, all the 9 S. piscifermentans isolates were tube and slide coagulase-negative, which agrees with Stetina et al. (2005). Meanwhile, all the 9 S. piscifermentans isolates were negative for lactose, mannose, oxidase activity, xylose and maltose, which are in agreement with the report of Stetina et al. (2005). Unlike most CoNS, S. piscifermentans has been generally reported as being susceptible in vitro to most antibiotics (Tan et al., 2008; Frank et al., 2008; Dundar et al., 2012).

In the present study, all the $9(100 \%)$ isolates of $S$. piscifermentans were susceptible to all the antimicrobial agents used including Oxacillin, penicillin and Vancomycin except tetracycline. Some $S$. piscifermentans isolates possessed SPA virulent gene but no mecA gene yet was susceptible to penicillin and Oxacillin, streptomycin, and gentamycin erythromycin, ampicillin, kanamycin, ciprofloxacin, chloramphenicol, and methicillin. However, the susceptibility of these 9 isolates to all the antimicrobial agents used may be due to the few numbers (9) of isolates. The resistance of $S$. piscifermentans to tetracycline could be associated with the frequent use of Oxytetraxycline by veterinarians to treat animal diseases and the rampant drug abuse and misuse use of tetracycline by the public. The result agrees with the report of Habeb and Mohammad (2010).

This confirmed that extensive use of antimicrobial agents in animal husbandry contributes to developing antibiotic-resistant microorganisms in animals and humans (Barber et al., 2003; Martín et al., 2006; Normanno et al., 2007; Allen, 2014). Based on these reservoirs, resistant strains or resistance genes may be distributed to humans through the food chain (Martín et al., 2006; Phillips et al., 2004; Verraes et al., 2013). 


\section{CONCLUSION}

The present study confirmed the presence of Staphylococcus piscifermentans in cattle, sheep and goats' as $4.6 \%$. Staphylococcus piscifermentans were demonstrated at a high rate in sheep $8.3 \%$ and the least was in goats $2.3 \%$. This is the first case report of $S$. piscifermentans in ruminants and their handlers in Northeastern Nigeria. The study also revealed that all except tetracycline could be used as a drug of choice to treat any case of Staphylococcus piscifermentans infestation. Finally, the present study revealed Staphylococcus piscifermentans isolated from ruminants and their handlers in Northeastern Nigeria possess SPA virulence genes.

\section{Declaration of Conflicting Interests}

The authors revealed that there was no potential conflicts of interest.

\section{REFERENCES}

ALI, FWO, ABDUL AMIR, A. S., MOHAMMED, AS, BAKAR, F. A., MANAP, Y. A., ZULKIFLI A. H., and SAARI, N., 2009. Novel, Practical and cheap source for Isolating Beneficial Y-Aminobutyric Acid Producing Leuconostoc NCS Bacteria. Res. J. Med. Sci 3(4): $146-153$.

ALLEN, H.K. 2014. Antibiotic resistance gene discovery in food-producing animals. Current Opinion in Microbiol. 19: 25-29.

BANNERMAN, T.L., and PAECOK.,S., 2007. Staphylococcus, Micrococcus, and other Catalase positive cocci. Manual of Clin. Microbiol. Vol. 19 Washington DC p 390.

BARBER, DA., MILLER, GY., and MCNAMARA, PE., 2003. Models of antimicrobial resistance and foodborne illness: examining assumptions and practical applications. J. Food Protect. 66: 700-709.

BODONAIK, N.C., and MOONAH, A. D. S., 2006. Coagulase -Negative Staphylococci from blood cultures contaminants or pathogens. West Indian med. 1. Vol. 55 (3), 174

CHINWE, E.O., EMMANUEL, O.N., SIMON I.E., ENID E.G., JOHN A.N., and KENNEDY F.C., 2018. Prevalence, toxigenic potential and antimicrobial susceptibility profile of Staphylococcus isolated from ready-to-eat meats, Vet. World, 2231-0916.

CLINICAL and LABORATORY STANDARDS INSTITUTE (CLSI)., 2014. Performance Standards for Antimicrobial Susceptibility Testing: Twenty-first Informational Supplement. CLSI Document 34:M100S24. Clinical and Laboratory Standards Institute, Wayne, PA.

FRANK, K. L., DEL POZO, J. L., and PATEL, R., 2008. From clinical microbiology to infection pathogenesis: how daring to be different works for Staphylococcus lugdunensis. Clin. Microbial Rev. 21: 111-133.

HABEEB,K., and MOHAMMAD A.,2010. Prevalence and Antibiotic Susceptibility pattern of methicillin-resistant and coagulase-negative Staphylococci in a tertiary care hospital in India. Int. J Med. Med. Sci.2 (4): 116 - 120.
HAJAR, S. and HAMID T.H.T.A., 2013. Isolation of Lactic acid bacteria strains Staphylococcus piscifermentans from Malaysian traditional fermented Shrimps Cincaluk. Int. Food Res. J. 20 (1): pp125-129.

HELLBACHER, C., TOMQVIST, E., and SODERQUIST, B., 2006. Staphylococcus lugdunensis: Clinical spectrum, antibiotic susceptibility and phenotypic and genotypic patterns of 39 isolates. Clin. Microbiol. Infect; 12:43-49.

HWANG, K.N., YUN, A.R., and RHEE, M.S., 200. Prevalence and classification of toxigenic Staphylococcus aureus isolated from refrigerated ready-to-eat foods in Korea. J. Appl. Microbiol., 70: 1153-1158.

KASSIS, C., RANGARAJ, G., and JAY, Y., 2009. Differentiating culture samples representing coagulasenegative Staphylococcus bacteraemia from those representing contamination by use of time to positivity and quantitative blood culture methods. J. Clin. Microbiol. 47(10): 3255- 3260.

MARTÍN, B., GARRIGA, M., HUGAS, M., BOVERCID, S., VECIANA-NOGUÉS, M.T., and AYMERICH, T., 2006. Molecular, technological and safety characterization of Gram-positive catalasepositive cocci from slightly fermented sausages. International Journal of Food Microbiology 107, 148.

MASHAK, Z., ALI, L.M., ALI, E., AYUB, E.F., and ASHKAN, I., 2015. Microbiological quality of readyto-eat foods of Tehran province. Afr. J. Food Sci., 9: 257-261.

MONK, A. B., BOUND, S., and CHU, V. H., 2008., analysis of the genotypic and virulence of Staphylococcus epidermidis isolates from patients with infective endocarditis. Infect. Immun., 76: 5127-5132.

NORMANNO, G., CORRENTE, M., LA SALANDRA, G., DAMbrosio, A., QUAGLIA, N.C., PARISI, A., GRECO, G., BELLACICCO, A.L., VIRGILIO, S., and CELANO, G.V., 2007. Methicillin-resistant Staphylococcus aureus (MRSA) in foods of animal origin product in Italy. International Journal of Food Microbiology 117, 219-222.

NYENJE, E.M., ODJADJARE, C.E., TANIH, N.F., and GREEN, E., 2012. Foodborne pathogens recovered from ready-to-eat foods from roadside cafeterias and retail outlets in Alice, Eastern Cape province, South Africa: Public health implications. Int. J. Environ. Res. Pub. Health, 9: 2608-2619.

ONYILOKWU, S.A., ADAMU, S. G., MAILAFIA, S., ATSANDA, N. N., TIJANI A. O., LAWAN, F. A., MUSA, J.A., and AMEH JA., 2016. Prevalence of Staphylococcus lugdunensis. Nasal colonization among apparently healthy ruminants and their human handlers in Maiduguri, Borno State, Nigeria. IOSR. J. Of Agric. And Vet. Sci. (IOSR- JAVS). 9 (8): 34-38.

O-SUllivan, L., ROSS, R. P., and HILL, C., 2002. Potential of bacteriocin-producing Lactic acid quality Biochimic. 84: 593-6.

PHILLIPS, I., CASEWELL, M., COX, T., DE GROOT, B., FRIIS, C., JONES, R., NIGHTINGALE, C., PRESTON, R., and WADDELL, J., 2004. Does the use of antibiotics in food animals pose a risk to human health? A critical review of published data. Journal of Antimicrobial Chemotherapy 53, 28-52 
SHUBHAM, G. R., PRADIP K. M., JANMEJAY P, S., SHARMA, S. C., and RANENDRA K. M., 2018. Isolation and Characterization of Predominant Bacteria, Staphylococcus piscifermentans Associated with Traditional Fermented Fish Products of Northeast India. Int. J. Curr. Microbiol. App. Sci., 7(5): 1758-71.

STETINA V., LAUKOVA A., STROMPFOVA, V., SVEC, P., and SEDLACEK I., 2005. Identification of Staphylococcus piscifermentans from dog faeces. Folia microbial 50(6), 524-528.

TAN, T. Y., NG, S. Y., and HE, J., 2008. Microbiological characteristics, presumptive identification, and antibiotic susceptibilities of Staphylococcus lugdunensis. J. Clin. Microbiol 46(7):2393-2395.

VERRAES, C., VAN BOXSTAEL, S., VAN MEERVENNE, E., VAN COILLIE, E., BUTAYE, P., CATRY, B., ET AL., 2013. Antimicrobial resistance in the food chain: A Review. Int. J. Environ. Res. Public Health 10, 2643-2669. doi: 10.3390/ijerph10072643

YASSER, S. M., ILKA, C., and LINESVENNESEN, K. H., 2018. Communications of Staphylococcus aureus and non-aureus Staphylococcus species from bovine intramammary infections and teat apex colonization. Journal of Dairy Science, 101(8): 7322-733.

VON EIFF, C., PETERS, G., and HEILMANN, C., 2002. Pathogenesis of infections due to coagulase-negative Staphylococci. Lancet. Infect. Dis. 2(11) 677-685.
How to cite this article:

Onyilokwu, S. A.; Adamu, S. G.; Lawan, F. A. and Aye, A. M., 2021. Occurrence of Staphylococcus piscifermentans among apparently healthy ruminants and their handlers in Maiduguri, Borno State, Nigeria. Journal of Applied Veterinary Sciences, 6 (4): 32 - 37. DOI:https://dx.doi.org/10.21608/javs.2021.88440.1094 